\title{
Niche overlap in fish assemblages inferred from canonical correspondence analysis: A case study with the Totkabon River, North of Iran
}

\author{
Mazaher Zamani Faradonbe - Soheil Eagderi* (i) Hadi Poorbagher \\ Department of Fisheries, Faculty of Natural Resources, University of Tehran, Karaj PO Box 4314, Iran \\ Corresponding author: soheil.eagderi@ut.ac.ir
}

Received date: $30.10 .2016 \quad$ Accepted date: 24.02 .2017

How to cite this paper:

Faradonbe, M.Z., Eagderi, S. \& Poorbagher, H. (2017). Niche overlap in fish assemblages inferred from canonical correspondence analysis: A case study with the Totkabon River, North of Iran. Ege Journal of Fisheries and Aquatic Sciences, 34(2): 151-156. doi:10.12714/egejfas.2017.34.2.06

\begin{abstract}
Twelve sites along the Totkabon River, north of Iran were sampled to study the relationship between fish assemblage and habitat variables, including elevation, water depth, river width, river slope, current velocity, number of large stone, average stone diameter, substrate index, potamal cover index and periphyton cover index. Canonical correspondence analysis was used to determine the relationship between fish assemblage and habitat variables. The results indicated that presence-absence and abundance of Alburnoides samiii were related to elevation, depth, number of large stone, stone diameter and velocity; presence-absence and abundance of Oxynoemacheilus bergianus, Cobitis keyvani, Barbus cyri, and Ponticola iranicus were related to number of large stone, stone diameter, velocity, elevation, and depth; and presence-absence and abundance Acanthobrama microlepis, Carassius auratus, and Pseurasbora parva are related with large stone, slope, elevation, and depth. The relationships between habitat variables and fish assemblage provide insight into their ecology and can aid effective fisheries management in the Sefidrud River basin.
\end{abstract}

Keywords: CCA, Totkabon River, Habitat variables, Fish assemblage, Sefidrud River drainage

\section{INTRODUCTION}

Spatial and temporal patterns of fish assemblages are central themes in stream ecology (Matthews, 1998). Those patterns in riverine fish are influenced by a number of biotic processes, including recruitment (Doherty and Williams, 1988), competition (Jones, 1991), and predation (Hixon, 1991; Hixon and Beets, 1993) plus abiotic parameters such as physical and chemical features, e.g. changes in flow, depth, substrate, and water quality (Capone and Kushlan, 1991). These spatial and temporal patterns provide a basis for classification and management of fish assemblages in aquatic ecosystems.

Anthropogenic activities may alter riverine ecosystems (Jennings et al., 1999) through changing the composition and density of macrophytes (Bryan and Scarnecchia, 1992), quantity and diversity of shoreline habitat (Christensen et al., 1996), and substrate composition (Jennings et al., 1996). To evaluate effects of anthropogenic-origined habitat changes on fish assemblages, the knowledge on the relationship between fish assemblage and environmental factors is required (Lester et al., 1996).

In recent years, several works investigated habitat loss and alteration as main factors threatening freshwater fish assemblages (Williams et al., 1989; Allen and Flecker, 1993; Richter et al., 1997). Hence, the relationship between quantitative fish assemblages and the environmental factors is advantageous for managerial purposes. It may be difficult to (c) Published by Ege University Faculty of Fisheries, Izmir, Turkey apply fish-environment relationships (models) procured from detailed, location-specific studies in other regions if stream conditions differ (Fausch et al., 1988). In addition, the ecology of many species varies across the range of their distribution.

There is no information on spatial and temporal patterns of fish assemblage and their relationship with environmental factors in the Totkabon River, a tributary stream of the Sefidrud River (the Caspian Sea basin, Iran). Therefore, this study aimed to examine the relationship between environmental factors and fish assemblage of this river to address important environmental factors, which determine fish composition and patterns of fish assemblages.

\section{MATERIALS AND METHODS}

Sampling: To evaluate how local environmental factors affect the distribution and abundance patterns of fish assemblage, we sampled fish and measured physical variables of habitat in autumn 2014 during base flow conditions. Thirteen sampling sites, distributed in elevation profiles, were selected to cover all available habitats along the Totkabon River in the Guilan Province of Iran (Figure 1). Sampling sites were $30 \mathrm{~m}$ apart. In all cases, fish were collected using backpack electrofishing device (Samus MP750, $45 \mathrm{~cm}$ diameter, aluminium ring anode) plus up- and down-stream stop-nets with $0.2 \mathrm{~cm}$ mesh size. For sampling, one-removal method with similar catch per unit of effort (CPUE) sampling strategy was 
employed (Klaar et al., 2004). The sampled fish were belonged to nine species and were returned to the river after identification and counting.

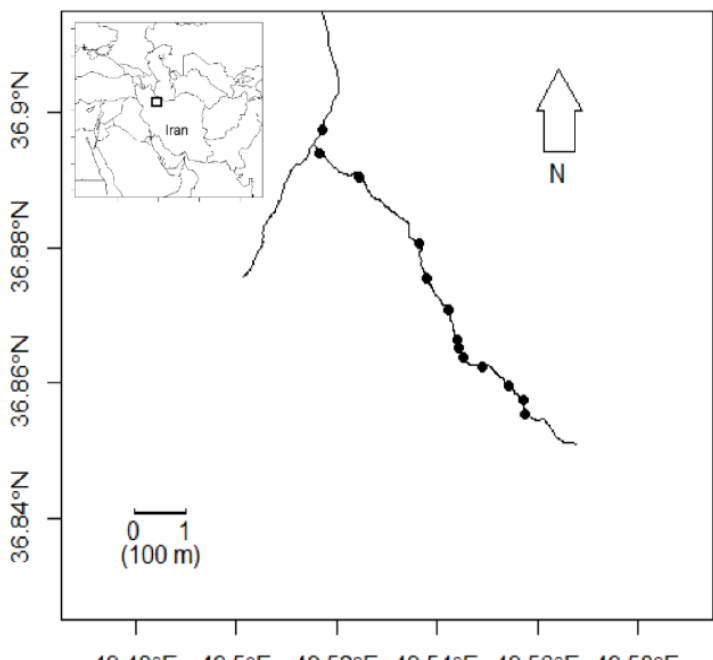

Figure 1. Map of sampling sites in the Totkabon River

Habitat Data: The measured habitat variables were: elevation $(\mathrm{m})$, water depth $(\mathrm{cm})$, river width $(\mathrm{cm})$, river slope $(\%)$, current velocity $\left(\mathrm{cm} \mathrm{s}^{-1}\right)$, number of large stone $(>25 \mathrm{~cm})$, average of stone diameter $(\mathrm{cm})$, substrate index (\%), potamal cover index $(\mathrm{PoCl})$, and periphyton cover index $(\mathrm{PeCl})$.

Elevation and geographical coordinates of sampling sites were recorded using a GPS (Garmin $\left.{ }^{\circledR}\right)$. The stream depth $(\mathrm{cm})$ was measured at 20 points across the sampling site using a graduated measuring bar, and their average was considered as river depth. Width $(\mathrm{cm})$ of the river was measured using a tapeline. The average of anterior, middle and end of each site was calculated as width of the river. Slope of the river was measured using a Suunto device (PM-PC Clinometer). Water velocity $\left(\mathrm{m} \mathrm{s}^{-1}\right)$ was measured using a floating object based on Hasanlie (1999), number of large stone $(>25 \mathrm{~cm})$ were found by counting the large stones in 20 selected quadrates $(50 \times 50)$ based on Lotfi (2012), the average of stone diameter was calculated by measuring the diameter of bed stones in 20 selected quadrated $(50 \times 50)$ based on Lotfi $(2012)$, and substrate index (SI) was calculated using the following formula: (Substrate Index) $\mathrm{SI}=0.08 \times \%$ bedrock $+0.07 \times \%$ boulder + $0.06 \times \%$ cobble $+0.05 \times \%$ gravel $+0.035 \times \%$ fines (Jowett et al., 2008). The Potamal Cover Index (PoCl) and Periphyton Cover Index $(\mathrm{PeCl})$ were determined using a ranking method (Platts et al., 1983) giving scores between 1-5 and 1-6, respectively for each site based on the percentage of surface covered by vegetation or periphyton (Tabatabaei et al., 2015).

Statistical Analysis: Canonical Correspondence Analysis (CCA) was used to examine the relationship between the structure of fish assemblage and environmental data (Jackson and Harvey, 1989). This is a method for direct gradient analysis in community ecology (ter Braak, 1986; Rodriguez and Lewis, 1997), describing the major trends in species distribution and correlated environmental parameters. The significance of environmental factors was assessed using "envfit" function after determination " $r$ " for environmental variables. A permutation test was used to examine significance of each environmental variable (1000 permutations) on all axes conjointly.

Primarily, all environmental variables were used in the CCA. The variance inflation factors (VIFs) were used to assess independence of variables. Variables with large VIFs (>20) were removed from the analysis to eliminate correlation among variables (ter Braak and Verdonschot, 1995). Some variables did not explain variation along major axes and were thus eliminated from the post-hoc analysis (Jongman et al., 1995; ter Braak and Verdonschot, 1995).

The CCA biplot graph was used to explain relationships between species and habitat factors. The speciesenvironmental biplot is an ordination diagram in which the species and environmental variables are shown as points and vectors, respectively. The vectors show the direction of maximum variation in value of the corresponding variable (ter Braak and Verdonschot, 1995).

\section{RESULTS}

Nine species were included in the final CCA analysis (Table 1). Range, mean, and standard deviation of the measures environmental variables of sampling sites are presented in Table 2. Variables in the final CCA were elevation, water depth $(\mathrm{cm})$, river width $(\mathrm{m})$, river slope $(\%)$, current velocity $\left(\mathrm{cm} \mathrm{s}^{-1}\right)$, number of large stone $(>25 \mathrm{~cm})$, and average stone diameter (cm). The removed variables with VIFs $>20$ were substrate index (\%), Potamal Cover Index (PoCl), and Periphyton Cover Index (PeCl). The relationships between seven selected habitat variables and structures of fish assemblage are depicted in Figures 2 and 3 . The position of a species relative to a vector of environmental variables indicates how the species is associated with the environmental variables.

Presence-absence data: The first two axes of CCA explained 36.85 and $31.41 \%$ (68.264 in total) of the variation in fish assemblages, respectively. The eigenvalues of axis 1 and 2 accounted 0.157 and 0.134 of the variance, respectively. Elevation (-0.51) and slope (0.53) were positively and negatively correlated, respectively, with the first ordination axis. Elevation (0.53) and depth (0.84) had positive, and width $(-0.74)$, slope $(-0.60)$, velocity $(-0.59)$, and stone diameter $(-0.61)$ negative correlation with the second axis (Table 3$)$. Nonsignificant environmental factors, identified in the stepwise forward selection process were substrate index, $\mathrm{PoCl}$ and $\mathrm{PeCl}$ that were ignored in CCA. 
Table1. Presence-absent data of sampling sites

\begin{tabular}{|c|c|c|c|c|c|c|c|c|c|c|c|c|c|}
\hline Species/sites & 1 & 2 & 3 & 4 & 5 & 6 & 7 & 8 & 9 & 10 & 11 & 12 & 13 \\
\hline Barbus cyri & + & + & + & + & + & + & + & + & + & + & + & + & \\
\hline Capoeta gracilis & + & + & + & + & + & + & + & + & + & + & + & + & + \\
\hline Alburnoides samiii & + & & & + & & & + & + & + & + & + & & + \\
\hline Acanthobrama microlepis, & & + & & + & + & & & & & + & & & + \\
\hline Ponticola iranicus & + & + & + & + & + & + & + & + & + & + & & + & \\
\hline Cobitis keyvani & + & + & + & + & & + & & & + & & & & \\
\hline Oxynoemacheilus bergianus & + & & + & + & + & + & & + & + & + & & & \\
\hline Carrassius auratus & & & + & & & & & & & & & & \\
\hline Pseuorasbora parva & & & + & & & & & & & & & & \\
\hline
\end{tabular}

Table 2. Range, mean, and standard deviation of the measured environmental variables of sampling sites

\begin{tabular}{lcc}
\hline Environmental variables & Range & Mean \pm SD \\
\hline Elevation $(\mathrm{m})$ & $129-208$ & $180.6 \pm 27.1$ \\
Depth $(\mathrm{cm})$ & $15-78$ & $34.1 \pm 17.64$ \\
Width $(\mathrm{cm})$ & $1.42-12.51$ & $5.5 \pm 3.13$ \\
Slope $(\%)$ & $0.37-2.4$ & $1.22 \pm 0.69$ \\
Velocity $\left(\mathrm{m} \mathrm{s}^{-1}\right)$ & $0.36-0.71$ & $0.53 \pm 0.10$ \\
Stone Diameter $(\mathrm{cm})$ & $2-222$ & $35.7 \pm 57.4$ \\
Number of large stones & $2-141$ & $42.8 \pm 39.8$ \\
Substrate index $(\%)$ & $0.047-0.071$ & $0.06 \pm 0.007$ \\
Temperature $\left({ }^{\circ} \mathrm{C}\right)$ & $13.5-15$ & $14.3 \pm 0.49$ \\
Potamal cover index & $1-5$ & $3.1 \pm 1.02$ \\
(PoCl) & & $4.5 \pm 0.87$ \\
Periphyton cover index & $4-6$ & \\
(PeCl) & & \\
\hline
\end{tabular}

The biplot generated by presence-absence data indicated that (1) presence-absence of Alburnoides samiii (Alsa) was positively related to elevation and depth and negatively with the number of large stone, stone diameter and velocity, (2) presence-absence of Oxynoemacheilus bergianus (Oxbe), Cobitis keyvani (Coke), Barbus cyri (Baci) and Ponticola iranicus (Poir) were positively related to the number of large stone, stone diameter and velocity and negatively with elevation and depth and (3) presence-absence of other species, including Acanthobrama microlepis (Acmi), Carassius auratus (Caur) and Pseudorasbora parva (Pspa) were not clearly related to any variables (Figure 2).

Abundance data: There was a significant relationship between abundance of fish species and environmental factors in CCA $(P<0.0001)$. The first two axes of CCA explained 44.782 and $28.044 \%$ (totally $72.826 \%$ ) of the variation in fish assemblages, respectively. The eigenvalues of axis 1 and 2 accounted 0.352 and 0.221 of the variance, respectively (Table 4). The results show that depth was positively (0.67), width (0.57 ) and slope (-0.58), were negatively correlated with the first ordination axis (Table 4). These factors represent the most important environmental factors related to the structure of fish assemblage. The river width $(-0.68)$ was negatively correlated with the second ordination axis (Table 4). Non-significant environmental factors in the stepwise forward selection process were substrate index, $\mathrm{PoCl}$ and $\mathrm{PeCl}$ being ignored in $\mathrm{CCA}$.

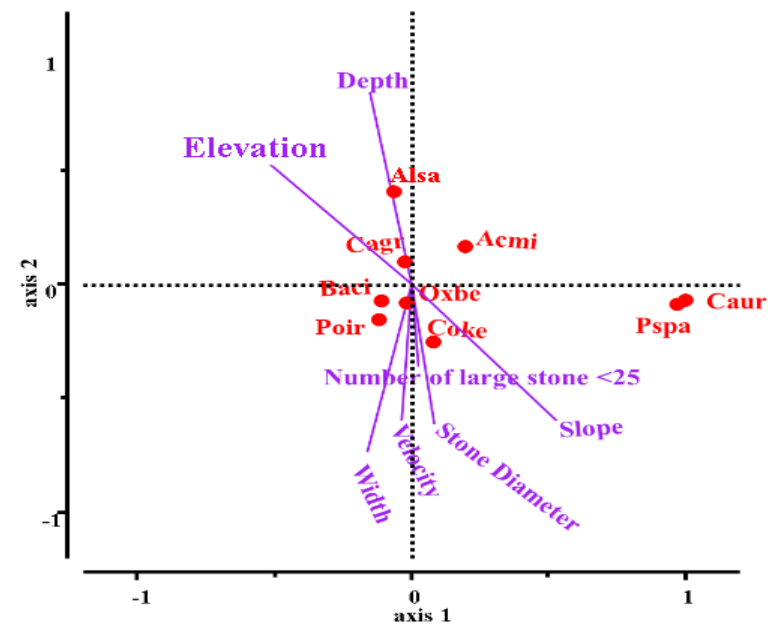

Figure 2. Canonical correspondence analysis (CCA), ordination diagram showing the effect of significant environmental variables on the structure of fish assemblages (presence-absence data)

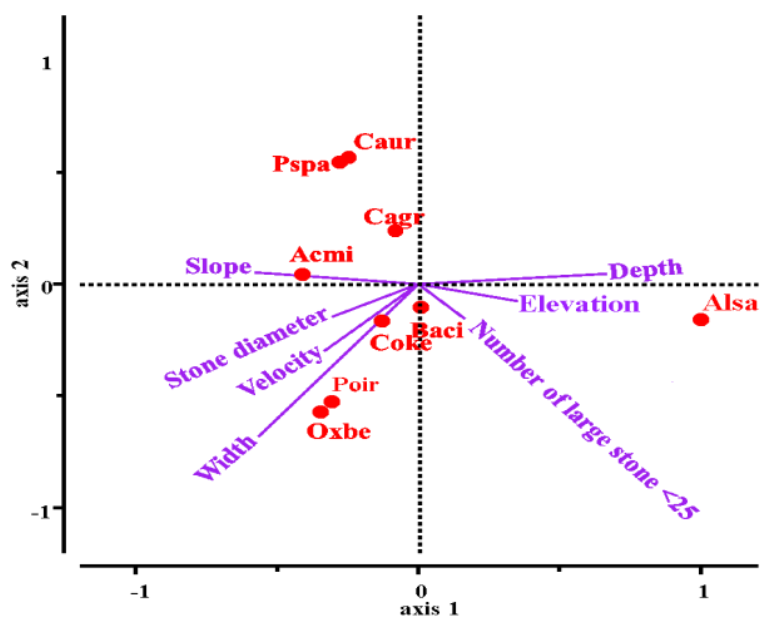

Figure 3. Canonical correspondence analysis (CCA) showing the effect of significant environmental variables on the structure of fish assemblages (abundance data) 
Table 3. Inter-set correlations of significant environmental variables with the first two ordination axes of the final canonical correspondence analysis (CCA) (presence-absence data)

\begin{tabular}{lcc}
\hline Environmental variable & CCA axis 1 & CCA axis 2 \\
\hline Elevation $(\mathrm{m})$ & -0.51 & 0.53 \\
Depth $(\mathrm{cm})$ & -0.15 & 0.84 \\
Width $(\mathrm{cm})$ & -0.12 & -0.74 \\
Slope & 0.53 & -0.60 \\
Velocity $(\mathrm{m} / \mathrm{s})$ & -0.01 & -0.59 \\
Average of Stone Diameter & 0.04 & -0.61 \\
Number of large stone & 0.01 & -0.35 \\
\hline Eigenvalue & 0.157 & 0.134 \\
Variance & 36.854 & 31.41 \\
\hline
\end{tabular}

Table 4. Inter-set correlations of significant environmental factors with the first two ordination axes of the final canonical correspondence analysis (CCA) (abundance data)

\begin{tabular}{lcc}
\hline Environmental variable & CCA axis 1 & CCA axis 2 \\
\hline Elevation $(\mathrm{m})$ & 0.35 & -0.08 \\
Depth $(\mathrm{cm})$ & 0.67 & 0.05 \\
Width $(\mathrm{cm})$ & -0.57 & -0.68 \\
Slope & -0.58 & 0.05 \\
Velocity $(\mathrm{m} / \mathrm{s})$ & -0.33 & -0.30 \\
Stone Diameter & -0.31 & -0.15 \\
Number of large stones & 0.16 & -0.16 \\
\hline Eigenvalue & 0.352 & 0.221 \\
Variance & 44.782 & 28.044 \\
\hline
\end{tabular}

The biplot generated by abundance data revealed that (1) abundance of $A$. microlepis (Acmi) was positively associated with slope and negatively with elevation and depth, (2) abundance of $P$. iranicus (Poir), C. keyvani (Coke) and $O$. bergianus (Oxbe) were positively related to stone diameter, velocity and width, (3) abundance of $C$. auratus (Caur), $P$. parva (Pspa) and Capoeta gracilis (Cagr) were negatively related to the number of large stone, (4) abundance of $A$. samiii (Alse) was negatively related to slope and positively to elevation, and (5) abundance of $B$. cyri (Baci) was positively related to the number of large stone (Figure 3)

\section{DISCUSSION}

The Totkabon River has a diverse fish fauna with high conservation importance. In this study, B. cyri, C. gracilis, 0 . Bergianus, and $P$. iranicus were the dominant assemblage as they occupied all possible habitats due to their high adaptability to a large range of environmental factors. Among the fish fauna of this river, two cyprinid species, i.e., $B$. cyri and $C$. gracilis are widely distributed in the studied sites (Jouladeh-Roudbar et al., 2015). Such widespread distribution and their great abundance suggest that these species are capable of tolerating a wide range of environmental conditions (Pusey et al., 1993).
The results showed that six variables, including elevation, depth, width, slope, velocity, and stone diameter influenced the presence-absence patterns of fish assemblage significantly. Depth, width, and slope influenced the abundance of fish assemblage at the Totkabon River significantly. The presence of species at habitat within its potential geographical range is affected by both historical, biogeographic conditions, such as prior colonization opportunities that explain the regional species pool, and contemporary local factors, such as small-scale habitat conditions (Jackson et al., 2001). Large streams have complex networks, and investigating small changes in entire fish community may help understanding the variables shaping species abundance (Gauch, 1982; ter Braak, 1986; Palmer, 1993). Elevation and longitudinal stream profile have long been recognized as influential factors in stream ecology (Vannote et al., 1980), especially in forested stream systems similar to that of the Totkabon River. A high water flow rate may also increase habitat area and turbidity, which may subsequently drop the potential for predation of species (Feyrer and Healey, 2003).

Our results indicated that the distribution of fish in the Totkabon River was largely influenced by the substrate characteristics, namely, abundance and diameter of large stones. These features have already been reported as important factors in distribution of stream fish assemblage (Erös et al., 2003; Carter et al., 2004). The substrate, per se, has an effect on other variables in rivers such as flow velocity and hence depth, resulting habitats with dissimilar features (Inoue and Nunokawa, 2002).

In the present study, the direct gradient analysis (CCA) found suites of environmental factors underlie the patterns of community structure across broad geographical scales. Water depth, current velocity, and substratum material features have been considered important factors that influence fish community structure (Gorman and Karr, 1978; Schlosser, 1982; Moyle and Vondracek, 1985; Bain et al., 1988; Lobb and Orth, 1991).

The results showed that the presence of some species in the assemblage were related to a range of a particular environmental factor underlining the hydraulic niche of species. For example, A. samiii were in deep areas of the river where pools were abundant. The occurrence of $C$. keyvani was coincided with low slope and substrate index, i.e., areas with slow water velocity and muddy-sandy substrates. In addition, the results showed that two exotic fish species, $P$. parva and $C$. auratus are found along the banks of rivers among vegetation where ponds are formed with slow water velocity although these characteristics were not among the examined factors in this study.

This study provided valuable information regarding effective environmental factors on species of the Tonekabon River which is a typical river in the southern Caspian Sea benefitting fisheries management and conservation. 


\section{REFERENCES}

Allen, J.D., \& Flecker, A.S. (1993). Biodiversity conservation in running waters Bioscience, 43: 32-43. doi: 10.2307/1312104

Bain, M.B., Finn, J.T., \& Booke, H.E. (1988). Stream flow regulation and fish community structure. Ecology, 69: 382-392. doi: 10.2307/1940436

Bryan, M.D., \& Scarnecchia, D.L. (1992). Species richness, composition, and abundance of fish larvae and juveniles inhabiting natural and developed shorelines of a glacial lowa lake. Environmental Biology of Fishes, 35: 329-341. doi: 10.1007/BF00004984

Capone, T.A., \& Kushlan, J.A. (1991). Fish community structure in dry season stream pools. Ecology, 72: 983-992. doi: 10.2307/1940598

Carter, M.G., Copp, G.H., \& Szomlai, V. (2004). Seasonal abundance and microhabitat use of bullhead Cottus gobio and accompanying fish species in the River Avon (Hampshire), and implications for conservation. Aquatic Conservation: Marine and Freshwater Ecosystems, 14: 395-412. doi: 10.1002/aqc.617

Christensen, D.L., Herwig, B.J., Schindler, D.E., \& Carpenter, S.R. (1996). Impacts of lakeshore residential development on course woody debris in north temperate lakes. Ecological Applications, 6: 1143-1149. doi: $10.2307 / 2269598$

Doherty, P.J. \& Williams. D.M. (1988). Are local populations of coral reef fishes equilibrial assemblages? The empirical data base, In Choat, J.H., D. Barnes, MA. Borowitzka, J.C. Coll, P.J. Davies, P. Flood, B.G. Hatcher, D. Hopley, P.A. Hutchings, D. Kinsey, G.R. Orme, M. Pichon, P.F. Sale, P. Sammarco, C.C. Wallace, C. Wilkinson, E. Wolanski \& O. Bellwood (eds.) Proceedings of the $6^{\text {th }}$ International Coral Reef Symposium, Townsville, Australia. Vol. 1: 131-139

Erös, T., Botta-Dukát, Z., \& Grossman, G.D. (2003). Assemblage structure and habitat use of fishes in a Central European submontane stream: a patchbased approach. Ecology of Freshwater Fish, 12: 141-150. doi: 10.1034/j.1600-0633.2003.00009.x

Fausch, K.D., Hawkes, C.L., \& Parsons, M.G. (1988). Models that predict standing crop of stream fish from habitat variables: 1950-1985. Department of Agriculture, Forest Service, Pacific Northwest Research Station, General Technical Report PNW-GTR-213, Portland, Oregon, U.S.A.

Feyrer, F., \& Healey, M.P. (2003). Fish community structure and environmental correlates in the highly altered southern Sacramento-San Joaquin Delta. Environmental Biology of Fishes, 66: 123-132. doi: 10.1023/A:1023670404997

Gauch, H.G. (1982). Multivariate analysis in community ecology. Cambridge University Press, New York. doi: 10.1017/cbo9780511623332

Gorman, O.T., \& Karr J.R. (1978). Habitat structure and stream fish communities. Ecology, 59: 507-515. doi: 10.2307/1936581

Hasanlie, A.M. (1999). Diverse methods to water measurement (Hydrometry) Shiraz University publication. 265 p. (In Persian)

Hixon, M.A. (1991). Predation as a process structuring coral reef fish communities. In: P.F. Sale (Ed.). The Ecology of Fishes on Coral Reefs (pp: 475-508). San Diego, CA: Academic Press doi: 10.1016/B978-0-08-092551-6.50022-2

Hixon, M.A., \& Beets, J.P. (1993). Predation, prey refuges, and the structure of coral-reef fish assemblages. Ecological Monographs, 63: 77-101. doi: $10.2307 / 2937124$

Inoue, M., \& Nunokawa, M. (2002). Effects of longitudal variations in stream habitat structure on fish abundance. Freshwater Biology, 47: 1594-1607. doi: 10.1046/j.1365-2427.2002.00898.x

Jackson, D.A., \& Harvey, H.H. (1989). Biogeographic association in fish assemblages: local vs regional processes. Ecology, 70: 1472-1484. doi: $10.2307 / 1938206$

Jackson, D.A., Peres Neto, P.R., \& Olden, J.D. (2001). What controls who is where in freshwater fish assemblages: the roles of biotic, abiotic, and spatial factors. Canadian Journal of Fisheries and Aquatic Sciences, 58: 157-170. doi: 10.1139/f00-239

Jennings, M.J., Bozek, M.A., Hatzenbeler, G.R., Emmons, E.E., \& Staggs, M.D. (1999). Cumulative effects of incremental shoreline habitat modification on fish assemblages in north temperate lakes. North American Journal of Fisheries Management, 19: 18-27.

doi: 10.1577/1548-8675(1999)019<0018:CEOISH>2.0.CO;2

Jennings, M.J., Johnson, K., \& Staggs, M. (1996). Shoreline protection study: a report to the Wisconsin state legislature. Wisconsin Department of Natural Resources, Publication PUBL-RS-921-96, Madison.

Jones, G.P. (1991). Postrecruitment processes. In: P.F. Sale (Eds.). The ecology of coral reef fish populations: a multifactorial perspective. (pp: 294-328). San Diego, CA: Academic Press.

doi: 10.1016/B978-0-08-092551-6.50016-7

Jongman, R.H., ter Braak, C.J., \& Van Tongeren, O.F. (1995). Data analysis in community and landscape ecology. Cambridge University Press, Cambridge. 324 p. doi: 10.1017/cbo9780511525575

Jouladeh-Roudbar, A., Vatandoust, S., Eagderi, S., Jafari-Kenari, S., MousaviSabet, H. (2015). Freshwater fishes of Iran; an updated checklist. AACL Bioflux, 8(6): 855-909.

Jowett, I.G., Parkyn, S.M., \& Richardson J. (2008). Habitat characteristics of crayfish (Paranephrops planifrons) in New Zealand streams using generalised additive models (GAM). Hydrobiologia, 596(1): 353-365. doi: 10.1007/s10750-007-9108-z

Klaar, M., Copp, G.H., \& Horsfield, R. (2004). Autumnal habitat use of nonnative pumpkinseed Lepomis gibbosus and associations with native fish species in small English streams. Folia Zoologica, 53(2): 189-202.

Lester, N.P., Dunlop, W.I., \& Willox, C.C. (1996). Detecting changes in the nearshore fish community. Canadian Journal of Fisheries and Aquatic Sciences, 53: 391-402. doi: 10.1139/f95-266

Lobb, M.D., \& Orth, D.J. (1991). Habitat use by an assemblage of fish in a large warm water stream. Transactions of the American Fisheries Society, 120: 65-78. doi: 10.1577/1548-8659(1991)120<0065:HUBAAO>2.3.CO;2

Lotfi, A. (2012). Guideline on rapid assessment of environmental features of rivers. Environment Protection Department of Iran Publication, Tehran, Iran. 120 p. (In Persian)

Matthews, W.J. (1998). Patterns in freshwater fish ecology. Reviews in Fish Biology and Fisheries, 8: 495-497. doi: 10.1007/978-1-4615-4066-3

Moyle, P.B., \& Vondracek, B. (1985). Persistence and structure of the fish assemblage in a small California stream. Ecology, 66: 1-13. doi: $10.2307 / 1941301$

Palmer, M.W. (1993). Putting things in even better order: the advantages of canonical correspondence analysis. Ecology, 74: 2215-2230. doi: $10.2307 / 1939575$

Platts, W.S., Megahan, W.F., \& Minshall, G.W. (1983). Methods for evaluating stream, riparian, and biotic conditions. Department of Agriculture, Forest Service, Intermountain Forest and Range Experiment Station, Ogden, USA. Technical report INT-138, $70 \mathrm{p}$

Pusey, B.J., Arthington, A.H., \& Read, M.G. (1993). Spatial and temporal variation in fish assemblage structure in the Mary River, south-eastern Queensland: the influence of habitat structure. Environmental Biology of Fishes, 37: 355-380. doi: 10.1007/BF00005204

Richter, B.D., Braun, D.P., Mendelson, M.A., \& Master, L.L. (1997). Threats to imperiled freshwater fauna. Conservation Biology, 11: 1081-1093. doi: 10.1046/j.1523-1739.1997.96236.x

Rodriguez, M.A., \& Lewis, Jr. W.M. (1997). Structure of fish assemblages along environmental gradients in floodplain lakes of the Orinoco River. Ecological Monographs, 67: 109-128. doi: 10.1890/0012-9615(1997)067[0109:SOFAAE]2.0.CO;2

Schlosser, I.J. (1982). Fish community structure and function along two habitat gradients in a headwater stream. Ecological Monographs, 52: 395-414. doi: $10.2307 / 2937352$ 
Tabatabaei, S.N., Hashemzadeh Segherloo, I., Eagderi, S. \& Zamani Faradonbeh, M. (2015). Habitat use of two nemacheilid fish species, Oxynoemacheilus bergianus and Paracobitis sp. in the Kordan River, Iran Hydrobiologia 762(1): 183-193. doi: 10.1007/s10750-015-2347-5

ter Braak, C.J.F. (1986). Canonical Correspondence Analysis: A new eigenvector technique for multivariate direct gradient analysis. Ecology 67(5): 1167-1179. doi: 10.2307/1938672

ter Braak, C.J.F., \& Verdonschot, P.F.M. (1995). Canonical correspondence analysis and related multivariate methods in aquatic ecology. Aquatic Sciences, 57: 255-289. doi: 10.1007/BF00877430
Vannote, R.L., Minshall, G.W., Cummins, K.W., Sedell, J.R., \& Cushing, C.E. (1980). The river continuum concept. Canadian Journal of Fisheries and Aquatic Sciences, 37: 130-137. doi: 10.1139/f80-017

Williams, J.E., Johnson, J.E., Hendrickson, D.A., Contreras-Balderas, S., Williams, J.D., Naarro Mendoza, M., McAllister, D.E., \& Deacon, J.E. (1989). Fishes of North America: endangered, threatened, or of special concern. Fisheries, 14(6): 2-20

doi: 10.1577/1548-8446(1989)014<0002:FONAET>2.0.CO;2 